\title{
Association of genetic variants of forebrain embryonic zinc finger-like (FEZL) gene exon 3 with clinical mastitis in Murrah buffaloes (Bubalus bubalis)
}

\author{
Bharat Kumar, Archana Verma and Ishwar Dayal Gupta
}

Received: 11 June 2020 / Accepted: 07 July 2020 / Published online: 10 September 2020

(c) Indian Dairy Association (India) 2020

\begin{abstract}
Forebrain embryonic zinc finger-like (FEZL) gene is an important candidate gene, which affects the host disease resistance. The gene has been mapped on BTA22 and consists of 6 exons and 5 introns spanning over $4685 \mathrm{bp}$. Present investigation was carried out with an aim to identify genetic polymorphism within exon 3 of FEZL gene and its association with incidence of clinical mastitis in Murrah buffaloes. Genomic DNA extracted from 110 Murrah buffaloes were amplified using two sets of primers and respective PCR products of $554 \mathrm{bp}$ and $474 \mathrm{bp}$ were obtained. A total of 4 nucleotide sequence variations in exon 3 were observed. Two SNPs g. 1556C $>$ T and g.1707G $>$ A were non synonymous, which resulted in amino acid substitution of isoleucine to threonine and methionine to valine at protein position 31 and 83, respectively. PCR-RFLP using MspI for primer 3.1 and DraI for primer 3.2 revealed monomorphic patterns, while TaqI for primer 3.1 exhibited polymorphism with CC, CT and TT genotypes with respective frequencies of $0.35,0.21$ and 0.44 . Association of identified genotypes with clinical mastitis has been found to be significant $(p<0.01)$. Odds Ratio $(\mathrm{OR})$ analysis confirmed significant association $(\mathrm{OR}=6.8531 ; 95 \% \mathrm{CI})$ and TT genotype of SNP g.1556C $>\mathrm{T}$ of FEZL gene emerged as the most favoured and may be used as a potential marker for selecting
\end{abstract}

Animal Genetics and Breeding Division

ICAR-National Dairy Research Institute, Karnal-132 001, India

Archana Verma ( $\square)$

Animal Genetics and Breeding Division

ICAR-National Dairy Research Institute

Karnal-132001, India

Email: archana.ndri@gmail.com

Tel: (O): 91-184-2259105; (M): 09416079659
Murrah buffaloes less susceptible to mastitis, after validation in a larger herd.

Keywords: FEZL, Genetic variants, Mastitis, Murrah buffalo, SNPs

\section{Introduction}

Mastitis, an inflammatory disease of the mammary gland, is generally caused by invading pathogens resulting in intramammary infections. It is the most devastating disease of dairy animals as well as dairy industry, due to treatment cost, reduction in milk production and milk quality, discarding milk and culling of the affected animals (Aitken et al. 2011). Generally, genetic variation in complex traits is controlled by a large number of loci with small to moderate effects (Kemper and Goddard, 2012). Moreover, breeders' focus has always been towards selection of animals for more milk production, which results in an increase in the mastitis incidences. Considering animal to animal variation in the occurrence of mastitis under same management system, role of genetics towards resistance/susceptibility to this disease is imperative (Rupp and Boichard, 2003). Consequently, search for potential genetic markers associated with udder health was attempted. Therefore, to decrease the incidence of mastitis and increase milk production of dairy animals, genetic variants in the candidate genes may be identified and included in marker-assisted selection (MAS) breeding programs (Loor et al. 2011; Pighetti and Elliott, 2011).

Mastitis causing bacteria invade the mammary gland, and produce harmful substances resulting in inflammation. In response to pathogen infiltration, the vertebrate immune system has evolved multiple defense systems, which can be broadly classified into innate and adaptive immunity, to repel and kill the invasive microbe. The innate immune response exists in all multicellular organisms and it is mediated by the physical barrier of the teat end, immunocytes such as macrophages, neutrophils, natural killer (NK) cells, and certain soluble factors (Sordillo and Streicher, 2002).The immunocytes have receptors called Pattern Recognition Receptors (PRRs), which recognize specific Pathogen Associated Molecular Patterns (PAMPs). The interaction between PRR and PAMP stimulates extra cellular 
complement pathway as well as intracellular signaling pathways culminating in inflammatory responses. The major PRRs involved in intracellular signaling pathways are Toll-like receptors (TLRs) and Nucleotide Oligomerization Domains (NODs). NODs are a family of cytosolic proteins that has been implicated in innate recognition of bacteria and host defense (Matteo et al. 2017). Forebrain embryonic zinc finger-like (FEZL) protein is an important member of this domain, which is involved in transcriptional regulation of neuronal development. The structure of $\mathrm{C} 2 \mathrm{H} 2$ type zinc-finger proteins is maintained and coordinated by zinc ions and contain two cysteines in one chain and two histidine in the other chain. Crystallographic studies revealed that classical zinc-finger domains have two $\beta$-sheets and one $\alpha$ helix. It has been established that there exists crosstalk between neuronal development and immunity via downstream cytokine expression. Zinc fingers act as regulators of $\mathrm{T}$ helper cell differentiation, cytokines, cytokine receptors, and other components of cytokine signaling pathways (Powell et al. 2019), inhibit the replication and expression of certain viruses, promote viral degradation (Ishida, 2020) and exhibit immunomodulatory function through activation of $\mathrm{T}$ lymphocyte differentiation, which provide defense against invading pathogens (Zhu et al. 2020).

Mastitis induces FEZL expression in mammary glands resulting in increased expression of the axon-attracting molecule semaphorin 5A (SEMA5A) which in turn induces expression of TNF- $\alpha$ and IL-8 (Sugimoto et al. 2006; Detilleux, 2009; Fonseca et al. 2011). Susceptibility to mastitis results from an impaired immune response due to the lower transcriptional activity of the gene. Thus, FEZL has been identified as one of the QTLs influencing mastitis in dairy animals (Ogorevc et al. 2009). Bovine FEZL gene has been mapped on BTA 22, spans over 4685 bp comprising of six exons, only four of which are coding with 459 amino acids long polypeptide (Sugimoto et al. 2006). Present study aimed to identify genetic variants in exon 3 of FEZL gene and their association with clinical mastitis in Murrah buffaloes.

\section{Materials and Methods}

\section{Selection of animals, blood collection and genomic DNA isolation}

A total of 110 Murrah buffaloes maintained at Livestock Research Center, ICAR-National Dairy Research Institute, Karnal were included in present study. Blood samples were collected from each animal by jugular vein puncture in a sterile vacutainer (Beckton-Dickinson vacutainer) containing 0.5\% EDTA solution (10 $\mu 1 / \mathrm{ml}$ of blood), which was duly approved by Institute Animal Ethics Committee (IAEC). Genomic DNA was isolated by phenolchloroform method described by Sambrook and Russell (2001). Data regarding incidence of clinical mastitis were recorded from the treatment register of Animal Health Complex and depending on the incidence of clinical mastitis, animals were categorized as healthy and mastitis affected. Cows which never suffered from mastitis up to first four lactations were classified as healthy, while those animals who suffered from mastitis were included in the affected category.

\section{PCR and sequencing}

Two sets of primers targeting partial intron 2 and exon 3 of FEZL gene were designed using Primer 3 software and synthesized from Eurofins.Polymerase chain reaction (PCR) was carried out in $25 \mu \mathrm{l}$ of reaction mixture containing 20 pmole of each primer, $200 \mu \mathrm{M}$ dNTP, 1 unit of Taq polymerase, 10XPCR buffer and $50 \mathrm{ng}$ of genomic DNA. PCR amplification was performed in a programmable thermal cycler (MJ Research, PTC 200) under the following conditions: initial denaturation at $95^{\circ} \mathrm{C}$ for $5 \mathrm{~min}$, followed by 35 cycles of denaturation at $94^{\circ} \mathrm{C}$ for $30 \mathrm{~s}$, annealing at $55^{\circ} \mathrm{C}$ and $53^{\circ} \mathrm{C}$ respectively for both the primers for $30 \mathrm{~s}$, extension at $72^{\circ} \mathrm{C}$ for $40 \mathrm{~s}$ and final extension at $72^{\circ} \mathrm{C}$ for $10 \mathrm{~min}$ and cooling at $4{ }^{\circ} \mathrm{C}$. The PCR products were loaded on $1.0 \%$ agarose gel in 1xTBE along with $100 \mathrm{bp}$ DNA marker and ethidium bromide $(1 \mu \mathrm{l} / 100 \mathrm{ml})$ staining and visualized, size estimated and documented under Gel Documentation system (Minibis). A single sharp band confirmed proper amplification of the target DNA. PCR products were custom sequenced with both forward and reverse primers through Ist BASE sequencing INT, Malaysia. The edited DNA sequences were aligned using ClustalW software and the SNPs were identified. Nucleotide sequences were translated using ExPASY translate tool and amino acid substitutions were analysed for their effect on protein function using SIFT software.

\section{PCR-RFLP}

Restriction enzymes were selected using NEBcutter V2.0. and the amplicons of 554bp and 474bp were subjected to restriction digestion to identify polymorphism. The RE digestion was set up with 6 units of enzyme, $6 \mu$ PCR product, $1.5 \mu l$ buffer and milliQ water to make up the reaction volume to $10 \mu l$ and the mixture was incubated for 6 hours at $37^{\circ} \mathrm{C}$ for MspI and DraI; $65^{\circ} \mathrm{C}$ for TaqI. The restriction fragments were resolved on $2.5 \%$ agarose gel with $100 \mathrm{bp}$ DNA ladder, visualized in UV transilluminator to screen for respective restriction bands.Genotype patterns were assessed and photographed with gel documentation system.

\section{Statistical Analysis}

The genotype and allele frequencies were calculated by simple scoring of homozygotes and heterozygotes. Population genetic indices viz. effective allele number $(\mathrm{Ne})$ to estimate reciprocal of homozygosity, Shannon Index (I) as a measure of gene diversity and PIC (Polymorphism Information Content) were estimated using POPGENE v 1.3.2 (population genetic analysis tool). The Odds Ratio (OR) between mastitis affected and non-affected genotypes were calculated. 


\section{Results and Discussion}

\section{SNP genotypes and population genetic indices}

Complete exon 3 of bubaline FEZL gene was amplified using two sets of forward and reverse primers. Amplicons of 554bp covering nt.1387..1940 and 474bp covering nt.1843..2316 of FEZL gene were obtained (Table 1). Nucleotide sequence alignment resulted in 4 SNPs in complete exon 3. Two SNPs: g. 1556C $>\mathrm{T}$ and g. $1707 \mathrm{~A}>\mathrm{G}$ are non-synonymous types of mutations resulted in amino acids substitution of isoleucine to threonine and methionine to valine at p. 31 and p. 83 respectively, while g. $1940 \mathrm{C}>\mathrm{T}$ and g. $1997 \mathrm{G}>\mathrm{T}$ were synonymous type of mutations. SIFT software indicated p.Met83Val substitution was tolerated, while AA substitution p.Ile $31 \mathrm{Thr}$ affect the protein function (deleterious) (Table 2). This amino acid replacement potentially influences neutrophil function through ligand response modification and disease resistance (Lee et al. 2006).
PCR-RFLP was carried out using MspI and TaqI for $554 \mathrm{bp}$ amplified fragment and DraI for $474 \mathrm{bp}$ amplicon. Exon 3.1-TaqI at locus g.1556C $>$ T exhibited polymorphism with CC, AT and TT genotypes, while monomorphism was revealed by other two amplicon-RE combinations. Frequencies of observed genotypes for the g.1556C $>\mathrm{T}$ polymorphisms in the mastitis affected and healthy buffaloes CC, TT, and CT were $0.51,0.24,0.25$, and 0.20 , $0.64,0.16$ respectively. The restriction fragment sizes, overall allele and genotype frequencies, population genetic indices are shown in Table 3. Genotypic and allelic frequencies were greater than 0.1 , thus qualifying for association analysis. PIC, $\mathrm{He}$ and $\mathrm{Ne}$ are the indices of evaluating the genetic variation in population since higher the values of PIC and $\mathrm{He}$, greater is the genetic variation. Effective Allele Number $(\mathrm{Ne})$ which estimates the reciprocal of homozygosity and Shannon index (I), estimates gene diversity. Since Ne value of detected alleles is closer to the absolute number, population distribution of the allele is more uniform and moderately polymorphic as evident by PIC ( 0.3785$)$. There is no similar report

Table 1 Primer sequences, their annealing temperatures and PCR products of FEZL gene in Murrah buffaloes

\begin{tabular}{llllc}
\hline $\begin{array}{l}\text { Gene } \\
\text { Region }\end{array}$ & Targeted Region & Primer Sequence (5'...3') & $\begin{array}{l}\text { Annealing } \\
\text { temperature }\left({ }^{\circ} \mathrm{C}\right)\end{array}$ & $\begin{array}{l}\text { Product } \\
\text { size }(\mathrm{bp})\end{array}$ \\
\hline Exon 3-1 & $\begin{array}{l}\text { 1387..1940 } \\
\text { Partial intron 2..partial exon 3 }\end{array}$ & $\begin{array}{l}\text { F:CTT TTC CGGAAT GCAGAC TT } \\
\text { R: CAC AGC CTG GTT GAT GAC C }\end{array}$ & 55 & 554 \\
Exon 3-2 & $\begin{array}{l}\text { 1843..2316 } \\
\text { Partial exon 3 }\end{array}$ & $\begin{array}{l}\text { F:AAACCAACT GTG GCG TGT G } \\
\text { R: TCACCT TTC CGCACACCT }\end{array}$ & 53 & 474 \\
\hline
\end{tabular}

Table 2 Nucleotide changes and amino acid substitution in exon 3 of FEZL gene in Murrah buffaloes

\begin{tabular}{|c|c|c|c|c|c|}
\hline S.No. & $\begin{array}{l}\text { Nucleotide } \\
\text { position }\end{array}$ & Gene Region & Type of Mutation & $\begin{array}{l}\text { Amino Acid } \\
\text { Substitution }\end{array}$ & SIFT* Prediction \\
\hline 1 & g.1556C $>\mathrm{T}$ & Exon 3 & Non-Synonymous & p.Ile31Thr & Affects protein function \\
\hline 2 & g. $1707 \mathrm{G}>A$ & & Non-Synonymous & p.Met83Val & Tolerated \\
\hline 3 & g. $1940 \mathrm{C}>\mathrm{T}$ & & Synonymous & p.Ala160Ala & - \\
\hline 4 & g.1997G $>\mathrm{T}$ & & Synonymous & p.Thr179Thr & - \\
\hline
\end{tabular}

Table 3 Overall genotypes, allele frequencies and genetic indices of FEZL loci in Murrah buffaloes

\begin{tabular}{|c|c|c|c|c|c|c|c|c|}
\hline $\begin{array}{l}\text { Exon-RE } \\
\text { combination }\end{array}$ & $\begin{array}{l}\text { Genotype/ } \\
\text { allele size (bp) }\end{array}$ & Frequency & $\begin{array}{l}\text { Allele } \\
\text { Frequency }\end{array}$ & & $\mathrm{Ne}$ & I & PIC & $\chi^{2}$ \\
\hline Exon 3.1- & $\mathrm{CC}:-$ & 0.00 & $\mathrm{C}$ & 0.00 & - & - & - & - \\
\hline MspI & $\begin{array}{l}\text { CG:- } \\
\text { GG:554 }\end{array}$ & $\begin{array}{l}0.00 \\
1.00(110)\end{array}$ & G & 1.00 & & & & \\
\hline Exon 3.1-Taq & CC:554 & $0.35(39)$ & $\mathrm{C}$ & 0.459 & 1.9963 & 0.6913 & 0.3785 & $0.003 *$ \\
\hline$I$ & $\begin{array}{l}\text { CT: } 170,384,554 \\
\text { TT: } 170,384\end{array}$ & $\begin{array}{l}0.21(23) \\
0.44(48)\end{array}$ & $\mathrm{T}$ & 0.541 & & & & \\
\hline $\begin{array}{l}\text { Exon 3.2- } \\
\text { DraI }\end{array}$ & $\begin{array}{l}\text { AA:- } \\
\text { AT:- } \\
\text { TT: } 474\end{array}$ & $\begin{array}{l}0.00 \\
0.00 \\
1.00(110)\end{array}$ & $\begin{array}{l}\mathrm{A} \\
\mathrm{T}\end{array}$ & $\begin{array}{l}0.00 \\
1.00\end{array}$ & - & - & - & - \\
\hline
\end{tabular}

Number of animals exhibiting a particular genotype has been indicated in parenthesis

*Significant $(\mathrm{P} \leq 0.01)$

$\mathrm{Ne}=$ Effective number of alleles; $\mathrm{I}=$ Shannon's information index;

PIC $=$ Polymorphic Information Content 
Table 4 Association of identified genotypes with incidence of clinical mastitis in Murrah buffaloes

\begin{tabular}{|c|c|c|c|c|c|}
\hline \multirow{2}{*}{ Locus } & \multicolumn{3}{|c|}{ Genotype frequency } & \multirow{2}{*}{$\begin{array}{c}\mathrm{P} \\
\text { value }\end{array}$} & \multirow{2}{*}{$\begin{array}{l}\text { Odds ratio } \\
(\mathrm{CI}=95 \%)\end{array}$} \\
\hline & Genotype & Mastitic $(n=55)$ & Non-mastitis $(\mathrm{n}=55)$ & & \\
\hline \multirow{3}{*}{$\begin{array}{c}\text { Exon 3.1- } \\
\text { TaqI }\end{array}$} & $\mathrm{CC}$ & 28 & 11 & \multirow{3}{*}{$\mathrm{P}<0.01$} & $\begin{array}{c}6.8531 \\
{[2.665-17.619]}\end{array}$ \\
\hline & CT & 14 & 09 & & 4.1880 \\
\hline & TT & 13 & 35 & & {$\left[\begin{array}{c}{[1.700-11.7)} \\
1\end{array}\right.$} \\
\hline
\end{tabular}

available in literature to compare and contrast the findings of present research on buffaloes. However, Dubey et al. (2014) observed monomorphic RFLP patterns using EaeI and MspI restriction enzymes for $978 \mathrm{bp}$ fragment covering intron 3 to intron 5 including exons 4 and 5 regions of FEZL gene in 20 healthy and 20 mastitis affected Murrah buffaloes. Ali et al. (2019) reported three SSCP patterns in 229bp amplicon with highest frequency: 0.8625 and 0.923 of A allele in mastitic and healthy cows respectively, while frequency of allele B was least $(0.0125)$ in mastitic and allele $\mathrm{C}(0.014)$ in healthy animals. They also reported that the population was not in HW equilibrium, suggesting selective advantage of G locus of FEZL gene. Sugimoto et al. (2006) also observed three genotypes with the highest (0.894) frequency of homozygotes in Holstein cattle.

\section{Association of genotypes with incidence of clinical mastitis}

Statistical analysis was carried out to find out association between genotypes of identified SNPs. Among the identified genotypes, animals with TT genotypes for SNP g. 1556C $>$ T showed significant association with mastitis. Odds Ratio analysis revealed strong association $(\mathrm{OR}=6.851,95 \% \mathrm{CI}=2.665-17.619)$ indicating that animals with $\mathrm{CC}$ genotype are at higher risk for mastitis, while those with TT genotype exhibit least susceptibility to the disease (Table 4). There are no reports regarding association with FEZL genotypes with mastitis in buffaloes, however, Sugimoto et al. $(2006 ; 2013)$ reported significant association of $12 \mathrm{G} / 13 \mathrm{G}$ polymorphism with SCC and mastitis in Japanese cattle. Ali et al. (2019) reported significant association of CC genotype having highest mean somatic cell counts $(674.92 \pm 48.1)$ compared to $\mathrm{AB}$ genotypes (226.16 \pm 4.9 ) with susceptibility to mastitis in Egyptian Holstein cattle, allele B was least frequent in mastitic animals, and allele $\mathrm{C}$ had the least frequency in normal animals. Moreover, the presence of allele (B) is associated with lower SCC while the presence of allele $(\mathrm{C})$ is associated with higher SCC indicative of higher susceptibility to mastitis. Fonseca et al. (2011) studied expression of mastitis-related genes, however, they did not find significant expression of FEZL gene in mastitis affected Holstein crossbred animals. Sugimoto et al. (2006) and Ali et al. (2019) reported increased expression of FEZL and SEMA5A genes in mastitic than healthy cows, due to enhanced antimicrobial/ immunomodulatory activity of FEZL, facilitating migration of neutrophils through induced production of interleukin 8 by TNF$\alpha$, which is effective for clearing infecting pathogens from host tissue (Sugimoto et al. 2006; Zhu et al. 2020). This further supports the role of FEZL as a potential genetic marker for mastitis resistance/susceptibility.

\section{Conclusions}

This is the first report on identification of SNPs/genetic variants of FEZL gene associated with incidence of clinical mastitis in buffaloes. It is evident from the findings of the present research that TT genotype of SNP g.1556C > in FEZL gene is a potential genetic marker for mastitis resistance, which could be exploited for marker-assisted selection (MAS) program aimed to improve mastitis resistance in buffaloes, after validation in larger population.

\section{Acknowledgement}

The authors are thankful to the Director, ICAR-National Dairy Research Institute, Karnal for all the facilities provided.

\section{References}

Aitken SL, Corl CM, Sordillo LM (2011) Immunopathology of mastitis: insights into disease recognition and resolution. J Mammary Gland Biol Neoplasia 16: 291-304

Ali GE, Ibrahim MA, Zaki SM (2019) Association assessment of single nucleotide polymorphism in Forebrain Embryonic Zinc Finger-Like (FEZL) gene with mastitis susceptibility in Holstein cattle (Bos taurus). Large Anim Rev 25: 163-171

Detilleux JC (2009) Genetic factors affecting susceptibility to udder pathogens. Vet Microbiol 134: 157-164

Dubey T, Sangwan ML, Wani SA, Kumar A, Gupta A, Kumari A, Rana V (2014) Forebrain embryonic zinc finger like gene polymorphism and its association with Mastitis in Murrah buffalo. J Cell Tissue Res 14: $4267-4272$

Fedota OM, Ruban SY, Bolotin VI, Klochko IO (2015) Genetics of resistance to clinical mastitis in cows: A review. J Vet Med Biotechnol Biosaf 1: 22-27

Fonseca I, Antunes GR, Lange CC, Guimarães SEF, Martins MF (2011) Expression of genes related to mastitis in cells of Holstein-Zebu crossbreed dairy cows. Genet Mol Res 10: 1295-1303

Ishida T (2020) Virucidal activities of zinc-finger antiviral proteins and zinc-binding domains for virus entry, DNA/RNA replication and spread. Edel J Biomed Res Rev 2: 9-13

Kemper KE, Goddard ME (2012) Understanding and predicting complex traits: knowledge from cattle. Hum Mol Genet 21: 45-51

Lee JW, Bannerman DD, Paape MJ, Huang MK, Zhao X (2006) Characterization of cytokine expression in milk somatic cells during 
intramammary infections with Escherichia coli or Staphylococcus aureus by real-time PCR. Vet Res 37: 219-229

Loor JJ, Moyes KM, Bionaz M (2011) Functional adaptations of the transcriptome to mastitis-causing pathogens: the mammary gland and beyond. J Mammary Gland Biol Neoplasia 16: 305-322

Matteo C, Smirnov A, Novelli F, Pitolli C, Agostini M, Malewicz M, Melino G, Raschellà G (2017) Zinc-finger proteins in health and disease. Cell Death Discovery 3: 17071

Ogorevc J, Kunej T, Razpet A, Dovc P (2009) Database of cattle candidate genes and genetic markers for milk production and mastitis. Anim Genet 40: 832-851

Pighetti GM, Elliott AA (2011) Gene polymorphisms: The keys for marker assisted selection and unraveling core regulatory pathways for mastitis resistance. J Mammary Gland Biol Neoplasia 16: 421-432

Powell MD, Read KA, Sreekumar BK, Oestreich KJ (2019) Ikaros Zinc Finger Transcription Factors: Regulators of Cytokine Signaling Pathways and $\mathrm{CD}^{+} \mathrm{T}$ Helper Cell Differentiation. Front Immunol 10: 1299

Rupp R, Boichard D (2003) Genetics of resistance to mastitis in dairy cattle. Vet Res 34: 671-688
Sambrook J, Russell DW (2001) Preparation and analysis of eukaryotic DNA. In: Molecular Cloning: A Laboratory Manual. 3rd Edition. Cold Spring Harbor Laboratory Press, New York: 6.1-6.62

Sordillo LM, Streicher KL (2002) Mammary gland immunity and mastitis susceptibility. J Mammary Gland Biol Neoplasia 7: 135-146

Sugimoto M, Fujikawa A, Womack JE, Sugimoto Y (2006) Evidence that bovine forebrain embryonic zinc finger-like gene influences immune response associated with mastitis resistance. Proc Natl Acad Sci USA 103: 6454-6459

Sugimoto M, Uchiza M, Kuniyuki M (2013) Effects of a Forebrain embryonic zinc finger-like p.Gly105(12_13) polymorphism on mastitis resistance: An embryo-transfer study. Mol BiolGenet Eng 1: $1-3$

Zhu M, Zhou J, Liang Y, Nair V, Yao Y, Cheng Z (2020) CCCH-type zinc finger antiviral protein mediates antiviral immune response by activating T cells. J Leukoc Biol 107: 299-307 